\title{
Effect of the Traditional Cooking Methods (Boiling and Roasting) on the Nutritional Profile of Quality Protein Maize
}

\author{
Omenna Emmanuel Chukwuma ${ }^{1}$, Olanipekun Oyeyoyin Taiwo ${ }^{1}$, Udouso Victory Boniface ${ }^{2}$ \\ ${ }^{1}$ Institute of Agricultural Research and Training, Obafemi Awolowo University, Moor Plantation, Ibadan, Oyo State, Nigeria \\ ${ }^{2}$ Federal College of Agriculture, Ibadan, Oyo State, Nigeria
}

Email address:

emmanuelomenna@gmail.com (O. E. Chukwuma)

\section{To cite this article:}

Omenna Emmanuel Chukwuma, Olanipekun Oyeyoyin Taiwo, Udouso Victory Boniface. Effect of the Traditional Cooking Methods (Boiling and Roasting) on the Nutritional Profile of Quality Protein Maize. Journal of Food and Nutrition Sciences.

Vol. 4, No. 2, 2016, pp. 34-40. doi: 10.11648/j.jfns.20160402.12

Received: January 12, 2016; Accepted: February 3, 2016; Published: May 11, 2016

\begin{abstract}
Freshly harvested yellow quality protein maize (QPM) was subjected to boiling and roasting. Proximate, nutrients and anti-nutrients analyses were carried out to investigate the effects of these treatments on the nutritional compositions and anti-nutrients content of quality protein maize. The result showed that the roasted quality protein maize (RQPM) had significantly higher crude proteins, crude fat, crude fiber, ash and carbohydrate value than the boiled quality protein maize (BQPM) and the raw (CQPM). There was an increased in energy value of roasted samples $(355.41 \mathrm{kcal} / 100 \mathrm{~g}) \mathrm{whereas}$ boiled samples recorded decreased energy value $(73.04 \mathrm{kcal} / 100 \mathrm{~g})$. Roasting had significantly increased the level of $\mathrm{Na}$, K, P, Ca and $\mathrm{Mg}$ while boiling slightly decreased the amount of these macro elements compared with the raw (CQPM). There was no significant difference in potassium content of all the samples. Roasted quality protein maize had higher amount of the micro elements (iron, zinc, copper, manganese, and selenium) than BQPM and CQPM. However, boiling had significantly reduced phytate content by $9.62 \%$ while roasting had $5.84 \%$ phytate reduction when compared with the raw. BQPM had significantly reduced oxalate by $7.03 \%$ while RQPM had $3.13 \%$ oxalate reduction. Both cooking methods (boiling and roasting) had similar reduction $(50 \%)$ of tannin. The results demonstrated that boiling was more effective in the reduction of anti-nutritional factors than roasting. Processing had significant impact on the fat soluble vitamins of quality protein maize. RQPM had the highest vitamin A with 88.24\% increment whereas BQPM had 8.78\% reduction of vitamin A. Similar trend was observed in vitamin E. The effect of processing on the beta -carotene of the quality protein maize was in the increasing order: $\mathrm{BQPM}<\mathrm{CQPM}<$ RQPM. The superiority of quality protein maize has been demonstrated by its high content of lysine (3.04\% for RQPM, 1.73\% for BQPM and 2.11\% for raw, CQPM) and methionine content ranges from 1.27 to $2.01 \%$ for boiled and roasted samples respectively. Roasting enhanced the nutritional values of quality protein maize by increasing the lysine and methionine content. These two essential amino acids are limited in other cereal crops. Boiling appeared to have experienced nutrients loss when compared with others. Therefore, nutritional values of quality protein maize could be harnessed by roasting to meet the nutritional needs of humans and may be used in formulation of various foods.
\end{abstract}

Keywords: Quality Protein Maize, Boiling, Roasting, Nutritional Composition

\section{Introduction}

Nutrients losses during food processing and the impact of anti-nutrient factors have become the issue of concern in the recent times. Optimum cooking treatments will not only minimize nutrients loss but also reduce the anti-nutrient factors. Natural toxicants (anti-nutrients) are always present in food materials. The presence of anti-nutrients affects the absorption and bioavailability of the food nutrients. Food processing therefore destroys (either by heat or other treatments) the concentration of toxins which exert adverse physiological effects when ingested by man and animals. This however affects the nutritional well-being and health of all people. Malnutrition still remains a widespread problem, and is particularly severe in developing countries with low per capital income. Maize is a major cereal crop for both livestock feed and human nutrition, worldwide. 
With its high content of carbohydrates, fats, proteins, some of the important vitamins and minerals, maize acquired a well-deserved reputation as a 'poor man's nutricerea [29]. Quality protein maize has recently attracted much attention from the international market because of their high content of essential amino acids such as lysine, tryptophan and threonine. Cereal proteins contain on an average about $2 \%$ lysine, which is less than one-half of the concentration recommended for human nutrition by the Food and Agriculture Organization of the United Nations. Therefore, healthy diets for humans and other monogastric animals must include alternate sources of lysine and tryptophan. Quality protein maize is rich for local consumption in the tropics where their role in the human diet is more important than their caloric value [33]. However, no research and development works have been conducted on the effective cooking methods that would improve the nutritional values of quality protein maize. It is imperative therefore to assess the impact of traditional processing on its nutritional superiority. This information poses a major problem for both consumers and farmers.

Objectives

The specific objectives of this research work were to investigate the effect of:

(1) Boiling on the macronutrients and micronutrients (minerals and vitamins) contents of quality protein maize(QPM)

(2) Roasting on the macronutrients and micronutrients (minerals and vitamins) contents of quality protein maize(QPM)

(3) Food processing on the anti-nutrient and proximate composition of quality protein maize(QPM)

(4) To develop adaptable and appropriate cooking methods of maize based on the traditional treatments with minimum nutrients loss.

\section{Method}

Sample preparation: cooking /boiling and roasting of Quality Protein Maize.

Three bunches/cobs of quality protein were cooked until the same degree of doneness as adjudged by using the sense organs of taste, smell and touch to determine when the corns were properly cooked. Three bunches/cobs of quality protein maize cob were roasted using charcoal fire.

Proximate analysis of the boiled (BQPM), roasted (RQPM) and raw samples which was the Control (CQPM). Samples were analysed chemically according to the official methods of analysis described by the Association of Official Analytical Chemists [1]. All analysis were carried out in triplicate. Weight of sample digested in milligram x Vol. of digest for steam distillation. The crude protein content is determined by multiplying percentage Nitrogen by a constant factor of 6.25 i.e. $\% \mathrm{CP}=\% \mathrm{~N}$ x 6.25 [1]

Moisture, protein, ash, crude fibre, fat, vitamins and minerals were carried out using standard methods (AOAC, 2005). Carbohydrate was determined by difference. Calorific values of samples were obtained by multiplying values of crude protein, crude fat and carbohydrate by 4,9 and 4 respectively [3].

\subsection{Oxalate Determination}

$2 \mathrm{~g}$ of sample was boiled in $40 \mathrm{ml}$ of water for 30 minutes in a reflux condenser. Add $10 \mathrm{ml}$ of $20 \% \mathrm{Na}_{2} \mathrm{CO}_{3}$ and boil for another 30 minutes. Filter the liquid extract and wash with hot water until the wash water does not show any alkaline reaction. Concentrate the combined wash water and filterate to a small volume and cool. With constant stirring, add $\mathrm{HCl}$ (1: 1) dropwise until the final acid concentration after neutralization is about $4 \%$ at which stage a heavy precipitate appears (which is allowed to flocculate). Carefully filter the extract into a $250 \mathrm{ml}$ flask and make up to mark. Keep overnight, then filter supernatant liquid through a dry filter paper in a dry beaker.

Take an aliquot of this filterate in a $400 \mathrm{ml}$ beaker, dilute with water to $200 \mathrm{ml}$ and make just ammoniacal, and reacidify with Lactic Acid. In the cold, medium, add $10 \mathrm{ml}$ of a $10 \%$ calcium chloride solution and stir well to include calcium oxalate precipitate to appear, and allow it settle overnight. Carefully decant the clean supernatant liquid off through Whatman No. 42 filter paper, without disturbing the precipitate. Dissolve the precipitate in HCL (1: 1). Oxalic acid is reprecipitated by adjusting the $\mathrm{pH}$ with ammonium hydroxide solution. Boil contents and allow to settle overnight. Determine oxalic acid by titrating against $0.05 \mathrm{~N}$ $\mathrm{KMnO}_{4}$ solution.

Calculation:

$1 \mathrm{ml}$ of $0.05 \mathrm{~N} \mathrm{KMnO}_{4}=0.00225$ anbydrous Oxalic Acid

$$
\begin{aligned}
& =\% \text { Oxalic Acid } \\
& =\frac{\text { Titre value } \times 0.00225}{2} \times \frac{100}{1} \\
& =\mathrm{T} . \mathrm{V} \times 0.1125 .[1]
\end{aligned}
$$

\subsection{Phytate Determination}

$2 \mathrm{~g}$ of each sample was weighed into $250 \mathrm{ml}$ conical flask. $100 \mathrm{mls}$ of $2 \%$ Hydrochloric Acid was added to soak each sample in the conical flask for 3 hours. This was filtered through a double layer of hardened filter paper. $50 \mathrm{ml}$ of each filterate was placed in $0.50 \mathrm{ml}$ conical flask and $107 \mathrm{mls}$ distilled water was added in each case to give proper acidity. $10 \mathrm{mls}$ of $0.3 \%$ Ammonium Thiocyanate $\left(\mathrm{NH}_{4} \mathrm{SCN}\right)$ solution was added into each solution as indicated. This was titrated with standard iron (III) chloride solution which contained $0.00195 \mathrm{~g}$ Iron per $\mathrm{ml}$. The end point was slightly brownishyellow which persisted for 5 minutes. The \% phytic acid was calculated using the formula:

$$
\% \text { Phytic acid }=\frac{\text { Titre value } \times 0.00195 \times 1.19 \times 100 \times 3.55}{\text { Wt.of Sample }}
$$

\subsection{Tannin Determination}

$0.20 \mathrm{~g}$ of sample was measured into a $50 \mathrm{ml}$ beaker $20 \mathrm{ml}$ of 
$50 \%$ methanol was added and covered with parafilm and placed in a water bath at $77-80^{\circ} \mathrm{C}$ for 1 hour. It was shaking thoroughly to ensure a uniform mixing. The extract was quantitatively filtered using a double layered Whatman No 41 filter paper into a $100 \mathrm{ml}$ volumetric flask, $20 \mathrm{ml}$ water added, $2.5 \mathrm{ml}$ Folin-Denis reagent and $10 \mathrm{ml}$ of $17 \% \mathrm{Na}_{2} \mathrm{CO}_{3}$ were added and mixed properly. The mixture was made up to mark with water mixed well and allow to stand for $20 \mathrm{~min}$. The bluish - green color will develop at the end of range 0$10 \mathrm{ppm}$ were treated similarly as $1 \mathrm{ml}$ sample above.

The absorbance of the Tannic acid standard solutions as well as samples were read after color development on a spectronic 21D spectrophotometer at the wavelength of $760 \mathrm{~nm}$. Tannin was calculated using the formula.

$$
\% \text { Tannin }=\frac{\text { absorbance of sample X average gradient factor X Dilution factor }}{\text { Wt of Sample X 10,000 }}
$$

\subsection{Determination of Vitamin E (Tocopherol)}

$1 \mathrm{~g}$ of sample was weighed into a $250 \mathrm{ml}$ conical flask filtered with a reflux condenser. $10 \mathrm{ml}$ of absolute alcohol and $20 \mathrm{ml}$ of IM alcoholic Sulphuric acid were added. The condenser and flask were wrapped in a luminum foil and refluxed for 45 minutes and cooled for 15 minutes. $50 \mathrm{ml}$ of distilled water was added to the mixture and transferred to a $250 \mathrm{ml}$ separating funnel covered with aluminum foil. The unsaponifiable matters in the mixture were extracted with $5 \mathrm{x}$ $30 \mathrm{ml}$ dimethyl ether. The combined extracts were washed free of acid and dry evaporated at a low temperature and the residues obtained were immediately dissolved in $10 \mathrm{ml}$ absolute alcohol. Aliquots of solutions of the sample and standards (0.3-3.0mg vitamin E) were transferred to a $20 \mathrm{ml}$ volumetric flask, $5 \mathrm{ml}$ Absolute Alcohol added, followed by a careful addition of $1 \mathrm{ml}$ conc. $\mathrm{HNO}_{3}$. The flasks were placed on a water bath at $90^{\circ} \mathrm{C}$ for exactly 3 minutes from the time the alcohol begins to boil. Cool rapidly under running water and adjust to volume with absolute alcohol. Measure the Absorbance at $470 \mathrm{~nm}$ against a blank containing $5 \mathrm{ml}$ absolute alcohol and $1 \mathrm{ml}$ conc. $\mathrm{HNO}_{3}$ treated in a similar manner.

$$
\text { Vitamin E }(\mu \mathrm{g} / 100 \mathrm{~g})=\frac{\text { Absorbances of sample } \mathrm{x} \text { Gradient factor } \mathrm{x} \text { Dil.Factor }}{\text { Wt of sample }}
$$

\subsection{Vitamin a Determination}

$2 \mathrm{~g}$ of each sample was weighed into a flat bottom reflux flask, $10 \mathrm{ml}$ of distilled water was added, shaked carefully to form a paste. $25 \mathrm{ml}$ of alcoholic $\mathrm{KOH}$ solution was added and a reflux condenser attached. The above mixture was heated in boiling water bath for 1 hour with frequent shaking. The mixture was cooled rapidly and $30 \mathrm{ml}$ of water was added. The hydrolysate obtained was transferred into a separatory funnel. The solution was extracted three times with $250 \mathrm{ml}$ quantities of chloroform. $2 \mathrm{~g}$ anhydrous $\mathrm{Na}_{2} \mathrm{So}_{4}$ was added to the extract to remove any traces of water. The mixture was then filtered into $100 \mathrm{ml}$ volumetric flask and made up to mark with chloroform. Standard solution of B-carotene Vitamin A of range $0-50 \mu \mathrm{g} / \mathrm{ml}$ with chloroform by dissolving $0.003 \mathrm{~g}$ of standard $\beta$-carotene in $100 \mathrm{ml}$ of chloroform. The above gradients of different standard solutions prepared were determined with reference to their Absorbances from which average gradient was taken to calculate Vitamin A (ß-carotene in $\mu \mathrm{g} / 100 \mathrm{~g}$ ). Absorbances of sample and standards were read on the Spectrophotometer (Metrohm Spectronic 21D Model) at a wavelength of $328 \mathrm{~nm}$.

Calculations:

$$
x \text { Vitamin A }(\mu \mathrm{g} / 100 \mathrm{~g})=\frac{\text { Absorbance of sample } x \text { Dilution Factor }}{\text { Wt.of Sample }}
$$

Calcium, potassium and sodium determination: The ash of each sample obtained was digested by adding $5 \mathrm{ml}$ of $2 \mathrm{M} \mathrm{HCl}$ to the ash in the crucible and heat to dryness on a heating mantle. $5 \mathrm{ml}$ of 2 MHCL was added again, heat to boil, and filtered through a Whatman No. 1 filter paper into a $100 \mathrm{ml}$ volumetric flask. The filterate was made up to mark with distilled water stoppered and made ready for reading of concentration of Calcium, Potassium and Sodium on the Jenway Digital Flame Photometer(PFP7 Model) using the filter corresponding to each mineral element [1]. The concentration of each of the element was calculated using the formula:

$$
\% \mathrm{Ca} \text { or } \% \mathrm{~K} \text { or } \% \mathrm{Na}=\frac{\text { Meter Reading (MR) } \mathrm{x} \text { Slope } \mathrm{x} \text { Dilution factor }}{100}
$$

NB: MR $x$ slope $x$ dilution factor will give you the concentration in part per million (ppm or $\mathrm{mg} / \mathrm{kg}$ ). You get concentration in \% when you divide by 10000 .

\subsection{Phosphorus Determination (Spectrophotometric Method)}

Phosphorus was determined routinely by the vanadomolybdate colorimetric or spectrophotometric method [1].

Determination: The ash of each sample obtained was treated $2 \mathrm{M} \mathrm{HCl}$ solution as described for calcium determination above. $10 \mathrm{ml}$ of the filterate solution was pipetted into $50 \mathrm{ml}$ standard flask and $10 \mathrm{ml}$ of vanadate yellow solution was added and the flask was made up to mark with distilled water, stoppered and left for 10 minutes for full yellow development. The concentration of phosphorus was obtained by taking the optical density (OD) or absorbance of the solution on a Spectronic 20 spectrophotometer or colorimeter at a wavelength of $470 \mathrm{~nm}$. The percentage phosphorus was calculated from using the formula:

$$
\% \text { Phosphorus }=\frac{\text { Absorbance } \mathrm{x} \text { Slope } \mathrm{x} \text { Dilution factor }}{10000}
$$




\subsection{Determination of $\mathrm{Se}, \mathrm{Cd}, \mathrm{Cu}, \mathrm{Mn}, \mathrm{Fe}$ and $\mathrm{Zn}$}

The digest of the ash of each sample above as obtained in calcium and potassium determination was washed into $100 \mathrm{ml}$ volumetric flask with deionised or distilled water and made up to mark. This diluent was aspirated into the Buck 200 Atomic Absorption Spectrophotometer (AAS) through the suction tube. Each of the trace mineral elements was read at their respective wavelengths with their respective hollow cathode lamps using appropriate fuel and oxidant combination.

\subsection{Statistical Analysis}

Data were analysed by the one way analysis of variance (ANOVA). Means were compared by the Duncan's multiple range test (DMRT) and significance was accepted at the 5\% level.

\section{Results and Discussions}

\subsection{Effect Processing on the Proximate Composition of QPM}

Table 1. Percentage proximate composition of raw and processed quality protein maize.

\begin{tabular}{llll}
\hline & Raw(CQPM) & Boiled(BQPM) & Roasted(RQPM) \\
\hline Crude Protein & $3.94 \pm 0.05 \mathrm{~b}$ & $2.84 \pm 0.06 \mathrm{c}$ & $7.00 \pm 0.11 \mathrm{a}$ \\
Crude Fat & $1.31 \pm 0.02 \mathrm{~b}$ & $1.08 \pm 0.03 \mathrm{c}$ & $4.65 \pm 0.02 \mathrm{a}$ \\
Moisture & $73.86 \pm 0.04 \mathrm{~b}$ & $81.53 \pm 0.04 \mathrm{a}$ & $8.77 \pm 0.02 \mathrm{c}$ \\
Ash & $0.88 \pm 0.01 \mathrm{~b}$ & $0.75 \pm 0.02 \mathrm{c}$ & $2.49 \pm 0.03 \mathrm{a}$ \\
Crude Fibre & $1.05 \pm 0.02 \mathrm{~b}$ & $0.81 \pm 0.02 \mathrm{c}$ & $2.20 \pm 0.02 \mathrm{a}$ \\
Carbohydrate & $18.96 \pm 0.03 \mathrm{~b}$ & $12.99 \pm 0.03 \mathrm{c}$ & $74.89 \pm 0.04 \mathrm{a}$ \\
Caloric & $103.39 \pm 0.03 \mathrm{~b}$ & $73.04 \pm 0.03 \mathrm{c}$ & $355.41 \pm 0.04 \mathrm{a}$ \\
Value(kcal/100g) & & & \\
\hline
\end{tabular}

Mean values of triplicate determination \pm standard mean error. Mean values with the same letter in a row are not significantly different $(\mathrm{p}<0.05)$.

Food processing may affect the functionality and nutritional quality of the food products. Effect of processing methods on the proximate composition of quality processed maize is given in table 1 above.

Protein content of RQPM sample was significantly higher $(\mathrm{P}<0.05)$ than CQPM and BQPM. This result indicated that heat treatment (roasting) improved the nutritional value of native protein. The proteins in raw samples were degraded and converted into soluble forms during boiling and this possibly led to low amount of proteins in BQPM. This observation agreed with other scientific findings that processing techniques such as germination and roasting improved the nutritional of food products particularly in terms of protein content [16]; [21]. This trend of decrease is similar to the observation made by Obasi and Wogu [23], who reported decrease in protein content of soaked yellow maize during soaking. The crude protein content of raw QPM was similar with that found in $\mathrm{P}_{1}$ - genotype QPM reported by Sentayehu [30].
Fat content of roasted sample, RQPM was significantly higher than CQPM and BQPM This result is in agreement with Kavitha and Parimalavalli [16], who stated that roasted maize flour had more fat than the germinated and raw flours. The increased in the fat content of roasted QPM when compared with the raw QPM may be attributed to the increase activity of lipolytic enzymes which produced more free fatty acids. There was $17.56 \%$ reduction in boiled sample, BQPM. This result indicates that the fat loss phenomenon was experienced in boiling.

Moisture content of boiled sample, BQPM was the highest $(81.53 \%)$ followed by CQPM (73.86\%) and least in roasted, RQPM $(8.77 \%)$. This result showed that roasting drastically reduced water activity. However, research had shown that the low moisture content of food samples is a desirable phenomenon since it reduces the microbial activity [17]. RQPM with low moisture content can be stored for a longer period of time without spoilage. It is note while that high moisture content in foods encourages microbial growth hence food spoilage may occur [27].

Roasted sample (RQPM) had the highest Carbohydrate content of $74.89 \%$ followed by the raw sample $(18.96 \%)$ while the boiled sample had least $(12.99 \%)$. This result was in contrast with the findings by Kavitha et al. [16] that raw maize flour $(97.60 \%)$ contained higher carbohydrate content than the roasted flour $(78.02 \%)$. Roasted quality protein maize proved to be a good source of energy.

Ash content of processed QPM samples varied significantly between $0.75 \%$ for BQPM and $2.49 \%$ for RQPM. The ash content of boiled sample was significantly lower than that of raw and roasted samples. The reduction in ash content may be due to the leaching of micro elements into the cooking/boiling water [19]. The roasted sample had significantly higher ash content than control, (raw) quality protein maize.

Similarly, RQPM had the highest fibre content $(2.02 \%)$ followed by CQPM (1.05\%) and least in BQPM (0.81\%). This implied the digestibility of maize since the food fibres are known to aid digestion. Dietary fibres facilitate digestion and are reported to prevent colon cancers by Olanipekun et al. [27].

\subsection{Effect of Processing on the Essential Amino Acids Content of QPM}

The nutritional superiority of quality protein maize has been demonstrated by its high content of lysine and methionine. Methionine content ranges from 1.27 to $2.01 \%$ for boiled and roasted samples respectively. These two essential amino acids are limited in other cereal crops [30]. Table 2 showed that roasted sample had significantly higher methionine and lysine than boiled and raw samples. Roasting enhanced the nutritional value of quality protein maize by increasing the lysine and methionine content. However, boiling appeared to have experienced nutrients loss when compared with raw and roasted samples. 
Table 2. Percentage essential amino acid concentration of processed QPM.

\begin{tabular}{llll}
\hline & $\operatorname{Raw}(\mathbf{C Q P M})$ & $\operatorname{Boiled}(\mathbf{B Q P M})$ & Roasted(RQPM) \\
\hline Methionine & $1.55 \pm 0.02 \mathrm{~b}$ & $1.27 \pm 0.02 \mathrm{c}$ & $2.01 \pm 0.03 \mathrm{a}$ \\
Lysine & $2.11 \pm 0.02 \mathrm{~b}$ & $1.73 \pm 0.02 \mathrm{c}$ & $3.04 \pm 0.02 \mathrm{a}$ \\
\hline
\end{tabular}

Mean values of triplicate determination \pm standard mean error. Mean values with the same letter in a row are not significantly different $(\mathrm{p}<0.05)$.

\subsection{Effect of Processing on the Vitamins Content of QPM}

Processing had a significant impact on the fat soluble vitamins of quality protein maize as shown in table 3. RQPM has the highest vitamin A with $88.24 \%$ increment whereas BQPM had $8.78 \%$ reduction of vitamin A, This could be due to oxidation. Food processing affect fat soluble vitamins which are susceptible to oxidation. Roasting had improved the bioavailability of vitamin A, which acts the precursor of visual pigment 11-cis-retinal. Vitamin $\mathrm{A}$ is essential in maintaining healthy vision and play. Therefore, intakes of quality protein maize is highly recommended to ameliorate the cases of night blindness and blindness. It is worthy to note that roasting had significantly increased the beta carotene content of quality protein. The effect of processing on the beta -carotene of the quality protein maize is in the increasing order: BQPM $<$ CQPM $<$ RQPM. This finding supported that observation of Wang and Russell [31] that food processing and heating increased the level of 9-Cis $\beta$ carotene. However, $\beta$-carotene has been shown to act as an immune modulator, quench singlet oxygen, and reduce peroxyl radicals at a low partial oxygen pressure [31]. Numerous animal and laboratory studies have substantiated $\beta$-carotene's ability to inhibit tumor cell growth and the progression of carcinogenesis [5]. Regular intake of roasted quality protein maize reduces the risk of lung and prostate cancers and therefore, this is recommended for smokers.

Table 3. Vitamin contents of raw and processed QPM (in $\mu \mathrm{g} / 100 \mathrm{~g}$ ).

\begin{tabular}{llll}
\hline & $\operatorname{Raw}(\mathbf{C Q P M})$ & Boiled(BQPM) & Roasted(RQPM) \\
\hline Vitamin A & $183.52 \pm 0.03 \mathrm{~b}$ & $167.41 \pm 0.03 \mathrm{c}$ & $345.45 \pm 0.15 \mathrm{a}$ \\
Vitamin E & $71.25 \pm 0.02 \mathrm{~b}$ & $58.93 \pm 0.04 \mathrm{c}$ & $86.73 \pm 0.02 \mathrm{a}$ \\
$\beta$-carotene & $48.19 \pm 0.02 \mathrm{~b}$ & $45.05 \pm 0.02 \mathrm{c}$ & $51.37 \pm 0.02 \mathrm{a}$ \\
\hline
\end{tabular}

Mean values of triplicate determination \pm standard mean error. Mean values with the same letter in a row are not significantly different $(\mathrm{p}<0.05)$.

Vitamin E was significantly higher in roasted sample, RQPM than CQPM and BQPM. It is noteworthy that quality protein maize is rich in antioxidants which are essential to prevent cancers and stress related diseases. The roasted sample had higher $\beta$-carotene than the raw and boiled samples. Heating improves the bioavailability of $\beta$-carotene by breaking down the carotenoid complexes [31]. Heat treatment resulted in improved nutritional retention and less vitamin loss as it were in boiling. This trend is in contrast with the results by Olanipekun et al. [27] which stated that boiling had significantly improved the nutritional value of kidney flour.

\subsection{Effect of Processing on the Mineral Elements Content of $Q P M$}

Quality protein maize is rich in micro- elements which play a vital role in the maintenance of human health. The iron content of processed QPM range from 4.95 to 7.10 $\mathrm{mg} / \mathrm{kg}$ for boiled and roasted samples respectively. Roasting had significantly improved the iron content, while boiling reduced the amount of iron. Roasted quality maize is good source of iron which is an important component of blood and enzymes involved in electron transfer. Its deficiency results in fatigue, headache and sore tongue in addition to anaemia [28]. The results showed that RQPM had the highest amount of $(5.90 \mathrm{mg} / \mathrm{kg})$ zinc followed by CQPM $(4.95 \mathrm{mg} / \mathrm{kg})$ and least in boiled sample, BQPM $(3.80 \mathrm{mg} / \mathrm{kg})$. The roasted whole grain of quality protein maize is a good source of zinc which plays essential role in normal taste sensation, protein and nucleic acid synthesis, carbohydrate metabolism, successful pregnancy, delivery and normal development [28] and. The bioavailability of $\mathrm{Cu}, \mathrm{Mn}$, and Se may due to the reduced amount of antinutritional factors which chelate with these minerals to form insoluble compounds.

There was no significant difference in calcium content of boiled and raw samples while the roasted sample had significantly higher in calcium $(\mathrm{p}<0.05)$ than others. Hence, supplementary infant feeding with quality protein maize is needed for bone and teeth formation while. Cereals and legumes are rich in minerals but the bioavailability of these minerals is usually low due to the presence of anti-nutritional factors such as phytate and polyphenoles [8]; [20]. An adequate mineral absorption is important for infants, children, older people and people in clinical situation [5]. The result of this work supported literature that different food processes such as soaking, germination and fermentation had significantly reduced of phytate content in cereals and vegetables. Phytic acid reduces the bioavailability of minerals [26]. Phytic acid as powerful chelating agent reduces the bioavailability of divalent cations by the formation of insoluble complexes [2]. This chelates divalent cations such as calcium, magnesium, zinc and iron, thereby also reducing their bioavailability [13]. The removal of undesirable components by processing is essential to improve the nutritional quality of cereals.

Table 4. Percentage (\%) concentration of Macro-elements in raw and processed QPM.

\begin{tabular}{llll}
\hline & Raw(CQPM) & Boiled(BQPM) & Roasted(RQPM) \\
\hline $\mathrm{Na}$ & $0.018 \pm 0.00 \mathrm{c}$ & $0.024 \pm 0.00 \mathrm{~b}$ & $0.057 \pm 0.00 \mathrm{a}$ \\
$\mathrm{K}$ & $0.280 \pm 0.00 \mathrm{a}$ & $0.297 \pm 0.13 \mathrm{a}$ & $0.330 \pm 0.00 \mathrm{a}$ \\
$\mathrm{Ca}$ & $0.003 \pm 0.00 \mathrm{~b}$ & $0.003 \pm 0.00 \mathrm{~b}$ & $0.051 \pm 0.00 \mathrm{a}$ \\
$\mathrm{P}$ & $0.117 \pm 0.00 \mathrm{~b}$ & $0.112 \pm 0.00 \mathrm{c}$ & $0.297 \pm 0.00 \mathrm{a}$ \\
$\mathrm{Mg}$ & $0.041 \pm 0.00 \mathrm{~b}$ & $0.026 \pm 0.00 \mathrm{c}$ & $0.106 \pm 0.00 \mathrm{a}$ \\
\hline
\end{tabular}

Mean values of triplicate determination \pm standard mean error. Mean values with the same letter in a row are not significantly different $(\mathrm{p}<0.05)$. 
Table 5. Micro-elements contents (in $\mathrm{mg} / \mathrm{kg}$ ) of raw and processed QPM.

\begin{tabular}{llll}
\hline & $\operatorname{Raw}(\mathbf{C Q P M})$ & Boiled(BQPM) & Roasted(RQPM) \\
\hline $\mathrm{Fe}$ & $5.55 \pm 0.15 \mathrm{~b}$ & $4.95 \pm 0.15 \mathrm{c}$ & $7.10 \pm 0.20 \mathrm{a}$ \\
$\mathrm{Zn}$ & $4.95 \pm 0.15 \mathrm{~b}$ & $3.80 \pm 0.10 \mathrm{c}$ & $5.90 \pm 0.20 \mathrm{a}$ \\
$\mathrm{Cu}$ & $0.61 \pm 0.03 \mathrm{~b}$ & $0.45 \pm 0.02 \mathrm{c}$ & $1.35 \pm 0.15 \mathrm{a}$ \\
$\mathrm{Mn}$ & $1.68 \pm 0.02 \mathrm{~b}$ & $1.56 \pm 0.02 \mathrm{c}$ & $2.20 \pm 0.10 \mathrm{a}$ \\
$\mathrm{Se}$ & $6.00 \pm 0.20 \mathrm{~b}$ & $4.75 \pm 0.15 \mathrm{c}$ & $7.25 \pm 0.15 \mathrm{a}$ \\
\hline
\end{tabular}

Mean values of triplicate determination \pm standard mean error. Mean values with the same letter in rows are not significantly different $(\mathrm{p}<0.05)$.

Table 6. Percentage composition of anti-nutrient factors of raw and processed QPM.

\begin{tabular}{llll}
\hline & Raw(CQPM) & Boiled(BQPM) & Roasted(RQPM) \\
\hline Phytate & $0.291 \pm 0.00 \mathrm{a}$ & $0.263 \pm 0.00 \mathrm{~b}$ & $0.274 \pm 0.00 \mathrm{~b}$ \\
Oxalate & $0.128 \pm 0.00 \mathrm{a}$ & $0.119 \pm 0.00 \mathrm{c}$ & $0.124 \pm 0.00 \mathrm{ab}$ \\
Tannin & $0.002 \pm 0.00 \mathrm{a}$ & $0.001 \pm 0.00 \mathrm{~b}$ & $0.001 \pm 0.00 \mathrm{~b}$ \\
\hline
\end{tabular}

Mean values of triplicate determination \pm standard mean error. Mean values with the same letter in a row is not significantly different $(\mathrm{p}<0.05)$.

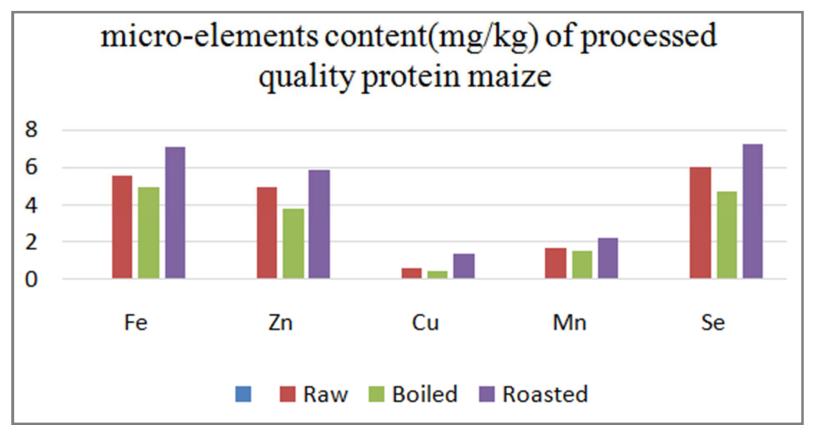

Figure 1. Micro-elements content of processed and raw quality protein maize.

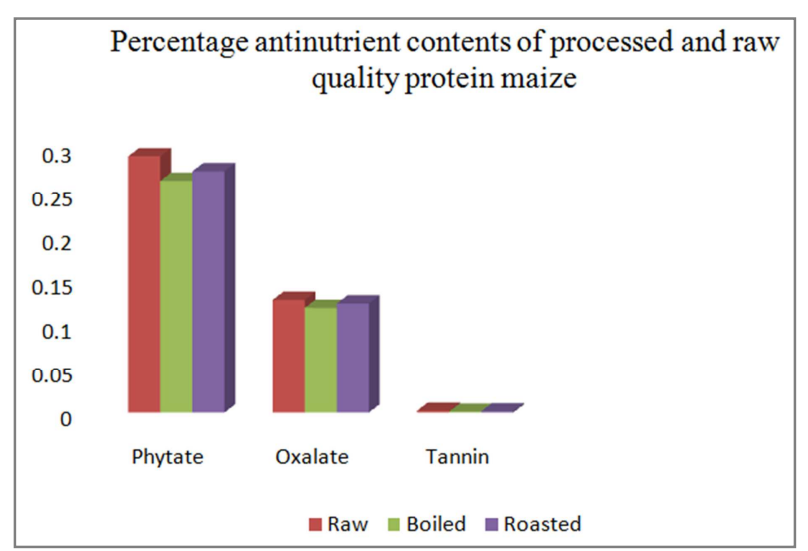

Figure 2. Anti-nutrients content of processed and raw quality protein maize.

\section{Conclusion}

This study concluded that quality protein maize is a nutritionally superior cereal with a substantial composition of methionine and lysine. Hence, traditional processing methods such as roasting had significantly improved the protein content and dietary fibres of quality protein maize as well as its vitamins and antioxidants in the form of $\beta$ - carotene which would be useful in neutralizing free radicals in the body and reduce harmful effect of oxidative stress. Roasting had significantly increased the concentration of macro and micro elements. Therefore, great nutritional values of quality protein maize could be harnessed by roasting to meet nutritional needs and may be used in formulation of various foods.

\section{Acknowledgment}

The authors appreciated the efforts of Mr Afolabi, O. O. in carrying out the laboratory bench works.

\section{References}

[1] AOAC, (2005). Official Methods of Analysis, Association of Official Analytical Chemists. 18th Edition. Pp. 114-222. Washington, DC, USA.

[2] Akpapunam, M. A. and Achinewhu, S. C. (1985). Effect of cooking, germination and fermentation on the chemical composition of Nigeria cowpea (Vigna unguiculata). Plant Food Hum. Nutr., 35, 353-358.

[3] Castenmiller, J. J. and West, C. E. (1998). Bioavailability and bioconversion of carotenoids. Annu Rev Nutr. 18: 19-38.

[4] Del-Rosano, R, R. and Flore, D. M. (1981). Functional properties of flour types of mung bean flours. J. Sci. Fd. Agric. 32: 175-180.

[5] De Flora, S., Bagnasco, $M$ and Vainio, H. (1999) Modulation of genotoxic and related effects by carotenoids and vitamin A in experimental models: mechanistic issues. Mutagenesis. 14: 153-172.

[6] Ebiokpor, R. A. and Lloyd, E. M. (2005). Pretreatment of African yam bean: effect of soaking and blanching on the quality of AYB seed. Plant foods for Human Nutrition. 60: 165-171.

[7] Elegbede, J. A. (1998). Legumes. In: Osagie, A. U. \& Eka, O. $U$. (eds), "Nutritional Quality of Plant Foods. Post Harvest Research Unit, Department of Biochemistry, University of Benin, Benin City, Nigeria. pp: 120-133.

[8] Eneche, E. H. (2003). Preparation and physiological properties of flours and protein concentrates from raw and germinated AYB (Sphenostylis stenocarpa). Proceedings of Annual Conference and Scientific meeting of Nutrition Society of Nigeria. 158-161.

[9] Enwere, N. J (1998). Foods of plant origin. Processing and utilization with recipe and technical profiles. Afrobis Publication ltd, Nigeria.

[10] Ezueh, M. I (1984). African yam bean as a crop in Nigeria. World crops 36: 199-200.

[11] Giami, S. Y. (1993). Effect of processing on the proximate composition and functional properties of cowpea (Vigna ungniculata) flour. Food Chem. 47, 153-158.

[12] Howard, I., Wong, A., Perry, A. and Klein, B. (1999). Bcarotene and ascorbic acid retention in fresh and processed vegetables. J. Food Sci. 64: 926-936

[13] Hsu, D. L., Leury, H. K., Finney, P. L. and Morad, M. M. (1980). Effects of germination on the nutritive value and baking properties of dry peas, lentils and faba beans. J. Fd. Sci. 45: 87-90. 
[14] Inyang, C. U. and Zakari, U. M. (2008). Effect of Germination and Fermentation of Pearl Millet on Proximate, Chemical and Sensory Properties of Instant "Fura"- A Nigerian Cereal Food. Pak. J. Nutr, 7(1): 9-12.

[15] Iwe, M. $O$ (2002). Handbook of sensory method and analysis. Rejoint Communications Services Ltd. Uwani-Enugu, Nigeria.

[16] Kavitha, S. and Parimalavalli, R. (2014) Effect of Processing Methods on Proximate Composition of Cereal and Legume flours. J Hum Nutr Food Sci. 2 (4): 1051-1055.

[17] Kordylas, J. M. (1990). Processing and preservation of tropical and sub-tropical foods. Macmillian Educational Ltd, Hampshire. Pp. 109-119.

[18] Kulkani, K. D., Kulkani, D. N. \& Ingle, U. M. (1991). Sorghum in malt based weaning food formulations; preparation, functional properties and nutritive value. $F d$. Nutr. Bull., 13, 322. Maga, J. A. (1983). Phytate: Its Chemistry: Occurrence, Food Interactions, Nutritional Significance and Method of Analysis.

[19] Myrene, R. and D'souza (2013). Effect of Traditional processing Methods on nutritional quality of field bean. $A d v$. Biores. 4: 29-33.

[20] Mohamed, R. K., Abou-Arab, E. A., Gibriel, A. Y., Nagwa M. H. Rasmy, H. M. and Abu-Salem, F. M. (2011). Effect of legume processing treatments individually or in combination on their phytic acid content. African Journal of Food Science and Technology 2(2): 036-046.

[21] Mubarak, A. E. (2005). Nutritional composition and antinutritional factors of mung bean seeds (Phaseolus aureus) as affected by some home traditional processes. Food Chem. 89: 489-495.

[22] Nwokolo, E. (1987). A nutritional assessment of African yam bean Sphenostylis stenocarpa (Hochst ex A. Rich) Harms and bambara groundnut Voandzeia subterranea L. J. Sci. Food Agric. 41: 123-129.

[23] Obasi, N. E. and Wogu, C. O. (2008). Effect of soaking time on the proximate and mineral compositions and antinutritional factors of yellow maize (Zea mays). Nig. Food J. 26(2): 69-77.
[24] Obatolu, V. A., Fasoyiro, S. B and Ogunsumi, L. (2001). Effect of Processing on Functional Properties of Yam Beans (Sphenostylis stenocarpa). Food Sci. Technol. Res., 7 (4), 319322 .

[25] Obizoba C. I. and Nnam, M. N. (1992). The effects of sprouting time on nutritive value of two varieties of African yam bean (Sphenostylis stenocarpa). Plant Fds. Hum. Nutr. 42: 319-327.

[26] Ofori, G., Oduro, I., Ellis, W. O. and Dapaah, K. H. (2009). Assessment of vitamin A content and sensory attributes ofnew sweet potatoes (Ipomoea batatas) geneotypes in Ghana. Afr. $J$. Food Sci. 3 (7): 184-192.

[27] Olanipekun, O. T., Omenna, E. C., Olapade, O. A., Suleiman, $P$. and Omodara, O. G. (2015). Effect of boiling and roasting on the nutrient composition of kidney beans seed flour. Sky J. Food Sci. 4: (2), 024-029.

[28] Onigbinde, A. O. (2005). Food and Human nutrition: Biochemical integration. In: biochemical interactions in food processing. Revised edn. Alva Corporate Organisation. Benin city. Pp 302-320.

[29] Prassanal, B. M., Vasal, S. K., Kassahum, B. and Singh, N. N (2001). Quality protein maize. Curr.Sci., 81: 1308-1319.

[30] Sentayehu, Alamerew (2008). Protein, tryptophan and lysine content in quality protein maize in North India. Ethiop. J. Health Sci.(18); 2: 10-16.

[31] Wang, X. D and Russell, R. M. (1999). Procarcinogenic and anticarcinogenic effects of beta-carotene. Nutr Rev. 1999; 57: 263-272.

[32] Vijayakumari, K., Siddhuraji, P. and Janardhanan, K. (1997). Effect of domestic processing the levels of certain antinutrients in Prosopis chilensis (Molina) Stunz. Seeds. Food Chem. 59(3): 367-371.

[33] Youseff, M. M., Abdal, M. A., Shekibs, L. A. E., and Ziena, H. $M$. (1989). Effects of dehulling, soaking and germination of chemical composition, mineral elements and protein patterns of feba beans (Vicia feba 1). Food Chem. 23: 129-136. 